\title{
УДК 378.174:004.588
}

\author{
Mykola M. Berezytskyi \\ postgraduate \\ Institute of Information Technologies and Learning Tools of NAES of Ukraine, Kyiv, Ukraine \\ m.berezitskyi@gmail.com
}

Vasyl P. Oleksyuk

$\mathrm{PhD}$ (pedagogical sciences), Associate Professor of the Department of Informatics and methods of its teaching Ternopil V. Hnatiuk National Pedagogical University, Ternopil, Ukraine

oleksyuk@fizmat.tnpu.edu.ua

\section{MASSIVE OPEN ONLINE COURSES AS A STAGE IN THE DEVELOPMENT OF E-LEARNING}

\begin{abstract}
The paper aims to trace back the history of e-Learning which encompasses the advent of m-Learning, the emergence of Smart University, massive open online courses (MOOCs) and cloud technologies. Special attention is given to the study of MOOCs phenomena. The article highlights characteristic features of two main types of MOOC: cMOOC and XMOOC in particular. The comparison of the MOOCs and traditional learning limitations and shortcomings, the statistic data regarding the MOOC platforms and students' enrolment, the analysis of differences between traditional distance courses and MOOCs, the main problems of MOOCs are considered in the paper.
\end{abstract}

Keywords: e-Learning; m-Learning; open education; cMOOC; xMOOC; MOOC-platform; traditional distance courses

\section{INTRODUCTION}

The problem setting. For many decades society has been trying to facilitate learning process. The problem is particularly acute for the sphere of IT, where the learning tools get updated very fast. The intensification of training is possible through using the e-Learning systems.

E-Learning plays an important role in the educational growth of every nation. For developing countries it offers opportunities to enhance their educational achievements. It can also play a crucial role in preparation of a new generation of teachers, as well as upgrading the skills of the present teaching staff to use 21st century tools and educational methods for learning. So, it is the changing trend in education. Modern technologies, the Internet in particular, made education no longer limited to the four walls of the classroom. An approach of 'no limitation' has caused the appearance of open education concept. Its development is observed during the last century. The latest educational tool is MOOC, a new form of organization and delivery of teaching and educational resources.

E-Learning comprises all forms of electronically supported learning and teaching. The information and communication systems, whether networked or not serve as specific media to implement the learning process. The term will still most likely be utilized to refer to the out-of classroom and in-classroom educational experiences via technology [1].

Today the e-Learning concept, apart from technology, embraces learning strategies, learning methods, and has lately directed to the vast possibilities of content diffusion and connection. The concept trend no longer means only the use of a computer as an artifact in the learning process [2].

E-Learning may be defined as an active process of transference and assimilation of knowledge, abilities, skills and ways of cognitive activity of a person by using information and communication technologies [3]. 
Online learning implies the use of the Internet to access learning materials to interact with the content, an instructor, and other learners; to receive support during the learning process, in order to acquire knowledge and to benefit from the learning experience.

Analysis of recent studies and publications. Researchers understand how complicated are the tasks of learning materials presentation and organization of full dialogue with students. They make efforts to improve learning process by searching new methodologies and approaches. Various aspects of e-Learning are being reflected in works of V. Bykov, M. Shyshkina, Y. Ramskyi, N. Balyk, O. Spirin, N. Morse, V. Kukharenko, O. Glazunova, L. Panchenko, D. Bruff, H. Kuzmenko, H. Singh, T. Tauber, S. Dhawal, J. Selingo, S. Georgiev, M. Sharples, S. Semerikov and others. Research of the last three authors addresses m-Learning and its problems. V. Kukharenko has the achievements in researching in the sphere of the system of distance learning through the open distance courses, namely by MOOCs. The MOOCs, its aspects and problems are highlighted in works of H. Kuzmenko, L. Panchenko, S. Dhawal, Todd Tauber and J. Selingo. Distance education and its prospects in Ukraine are described in the scientific works of V. Bykov, who along with M. Shyshkina examines the potential of cloud technologies and the ways of their implementation in education.

The article's goal is to analyze the main stages of the development of e-Learning with focus on the MOOCs; to prove that MOOC is a regular stage of e-Learning and can be used as an educational tool; to show MOOC's advantages and disadvantages; and to reveal the reasons of its key problem.

\section{METHODS OF THE STUDY}

The analysis of philosophical, pedagogical and psychological literature conducted with the aim to achieve the goals set made it possible to clarify the nature of the basic concepts of research, to systematize and generalize the theoretical and empirical data.

\section{THE RESULTS OF THE STUDY}

The first experiments on using the computers in training began in the late fifties of the 20th century. Professor B. F. Skinner put forward the idea of the programmed training. [4]. It was an attempt of automation of educational process by the way of constructing it according to the theory of management. At that time the implementation of various educational and controlling devices was observed. They were used for forming separate skills [5] and realization of the selective control. Later the notion of «e-Learning» was based on the concept of Computer-Assisted Instruction [6]. At the same time computers were mainly used during the study of programming, mathematics, economy etc.

In the 1970s the main models for the transmission of knowledge were designed, and the first systems based on the methods of the theory of Artificial Intelligence appeared. Scientists had been working on designing the systems to substitute the teacher [7].

A basic scientific objective of machine learning is the exploration of alternative learning mechanisms, including the discovery of different induction algorithms, the scope and limitations of certain methods, the information accessible to the learner, the issue of coping with imperfect training data, and the creation of general techniques applicable in many task domains [8].

In the 1980s the development of e-Learning systems was connected with the means of expert system using. Their benefits consisted in forming an active way of fixing the results of psychic activity, providing an access to practically unlimited volume of data. 
The methodological system of teaching via expert system was suggested by Ukrainian scientists Y. Ramskyi and N. Balyk [9].

A wide implementation of the PCs in learning process and development of the computer networks were the main tendencies in the 1990s. The concepts of «e-Learning» and «Distance-learning» emerged at that time. Historically distance education has more than one hundred years of experience and traditions. Its main characteristic feature is the distance and time separation between teacher and students. E-Learning offers new methods for distance education based on computer and net technologies.

Since 1997 these terms have been used to designate several ways that modern computers can be used to make the educational process more efficient [10]. E-Learning concept refers to learning via electronic sources, providing distance learning [11].

But the e-Learning system is related to the series of activities that are not necessarily connected with distance learning. In fact, there are components of e-Learning that can be used in any educational environment. M. Cernat argues that the best way of rendering the proper meaning of concept of «e-Learning» is to think of e-Learning system that provides the process of digital resources involvement for educating people [12]. All teaching and learning systems should be built from two vantage points: the needs of the target students, and the intended learning outcomes of the course or program - i.e., the knowledge, skills, and attributes that students will gain. An ideal online learning system will be based on a plan that flows from a full understanding of these two fundamentals [34].

The development of mobile technologies has caused the appearance of «MobileLearning» concept. M-Learning aims to make the learning environment and resources more flexible and versatile [13].

By nature the m-Learning is a form of combining d-Learning and e-Learning. It is a part of e-Learning and, therefore, a part of d-Learning. S. T. Georgiev believes that definition of m-Learning must include the ability to learn anywhere and anytime without permanent physical connection to cable networks. This can be achieved by the use of mobile and portable devices. They must have a possibility to connect to other computer devices, to present educational information and to realize two-side information exchange between the students and the teacher [14].

M-Learning combines e-Learning and mobile computing. It is sometimes considered merely as an extension of e-Learning, but quality of m-Learning can only be delivered with an awareness of the special limitations and benefits of mobile devices. M-Learning has the benefits of mobility and its supporting platform. It is a tool to enhance the broader learning experience. M-learning is a powerful technology for engaging learners on their own terms. Regardless of some differences between e-Learning and m-Learning, they are closely related.

Another concept of e-Learning was «Mega-University» that combines distance learning, higher education and use of technologies. John S. Daniel defines a mega-university as a distance-teaching institution with over 100,000 active students in degree-level courses [16].

N. Morze and O. Glazunova suggest the concept of «Smart Universities» where the educational discipline module is the information and didactic unit, in which the approach to structuring the whole into parts is unified. It has a complex structure that includes the goal of its integral development, objectives, content and results with the corresponding system of formative assessment [17].

In the attempt to determine the nature of MOOC it is necessary not to overlook the extremely powerful tool of providing a lot of possibilities into informative sphere and eLearning in particular. By this we mean cloud technologies. Cloud computing has made a great impact on education in general and on technical and vocational education in particular. The most important feature of the ICT tools of a new age is a degree of adaptation to the learner or customer demands. Cloud computing is a technology of network distributed data 
processing for which information resources and computing power are flexibly configured according to computer resources and procedural needs of users and are provided according to their requests as Internet services. Implementation of cloud computing in the learning process provides the potential for a fundamental renewal of content-target and technological aspects of the learning process that is realized in enrichment of teaching techniques, training tools and formation of new teaching technologies on this basis [24].

The next stage in the development of e-Learning is MOOC, which first appeared in literature in around 2010. According to McAuley, MOOC integrates the connectivity of social networking, the facilitation of an acknowledged expert in a field of study, and a collection of freely accessible online resources [19].

The key goal was "for people to experience what it means to be part of a social, technical system of learning where the teacher's voice is not an essential hub but, instead, a node in an overall network" [20].

The first MOOC took place in 2008 as an open online course at the University of Manitoba, Canada. The course, Connectivism and Connective Knowledge (CCK08) was facilitated by George Siemens and Stephan Downes, who have been developing the pedagogical theory of Connectivism and have regarded MOOCs as practical implementations of their theory (Siemens, 2012). All course content was available through RSS feeds, and online students could participate through a variety of collaborative and social tools, including blog posts, threaded discussions in Moodle, and Second Life online meetings [21-22].

The term MOOC was coined in 2008 by Dave Cormier of the University of Prince Edward Island and senior research fellow Bryan Alexander of the National Institute for Technology in Liberal Education in response to mentioned above CCK08 course. Dave Cormier joined in facilitating several other MOOCs, including PLENK 2010 (Siemens, Downes Cormier, \& Kop, 2010) that has been described as "a conglomerate consisting of various layers: live sessions... recordings.... complexity of discussion forum... the course Wiki and Blog... and the unique course aggregator named the Daily" (Levy, 2011). MOOCs of that type were later labeled "Connectivist MOOCs" (see below), to distinguish them from the current wave of MOOC offerings that share a little with Connectivist pedagogy [21-22].

Soon other independent MOOCs emerged. Jim Groom from The University of Mary Washington and Michael Branson Smith of York College, City University of New York adopted the CCK08 course structure and hosted their own MOOCs through several universities [21].

Early MOOCs departed from formats that relied on posted resources, learning management systems, and structures that mix the learning management system with more open web resources. MOOCs from private, non-profit institutions emphasized prominent faculty members and expanded open offerings to existing subscribers (e.g., podcast listeners) into free and open online courses.

These early MOOCs were less about presenting content and more about connecting learners. The term cMOOC refers to a MOOC designed to emphasize connecting learners. The challenge is for each learner to construct a personal learning network (PLN), by eliciting what is personally meaningful from the network of information and interactions. Such learning is "...highly social. The learning comes from content presented by a lecturer, and then dialog via social media, where the contributions of the participants are shared" (Quinn, 2012). Table 1 lists the most noteworthy c-MOOCs that have taken place during 2008-2012 years. These c-MOOCs are revolutionary since they erase existing boundaries between the institution and the outside world. Such Connectivist-based MOOCs call into question academic responsibility and institutional accountability. However, the seeds of the MOOC that were first spread as practical implementations of Connectivist theory have been supplanted by their next generation [22]. 
Connectivist MOOCs offered since the 1st MOOC in 2008

\begin{tabular}{|l|l|}
\hline Year & \multicolumn{1}{c|}{ Course Title } \\
\hline 2008 & Connectivism (Fall 2008) - the first MOOC \\
\hline 2009 & Connectivism (Fall 2009) Connect! Your PLN Lab (Fall 2009) \\
\hline 2010 & PLENK - Personal Learning Environments Networks and Knowledge (Fall 2010) \\
\hline & $\begin{array}{l}\text { Channel MOOC-Change: Education. Learning, and Technology! (Fall 2011) } \\
\text { eduMOOC - Online Learning Today and Tomorrow (Summer 2011) }\end{array}$ \\
$\begin{array}{l}\text { DS106 - Digital Storytelling (Summer 2011) } \\
\text { MobiMOOC - Mobile Learning (Spring 2011) } \\
\text { LAK11 - Learning and Knowledge Analytics (Spring 2011) } \\
\text { CCK11 - Connectivism and Connective Knowledge (Spring 2011) }\end{array}$ \\
\hline 2011 & $\begin{array}{l}\text { Mobi-MOOC } \\
\text { Games Based Learning MOOC, a mini-MOOC, a meta-MOOC, a MOOC about MOOCs. }\end{array}$ \\
\hline
\end{tabular}

In the image below (Figure 1) you can see a timeline of MOOC development [21].

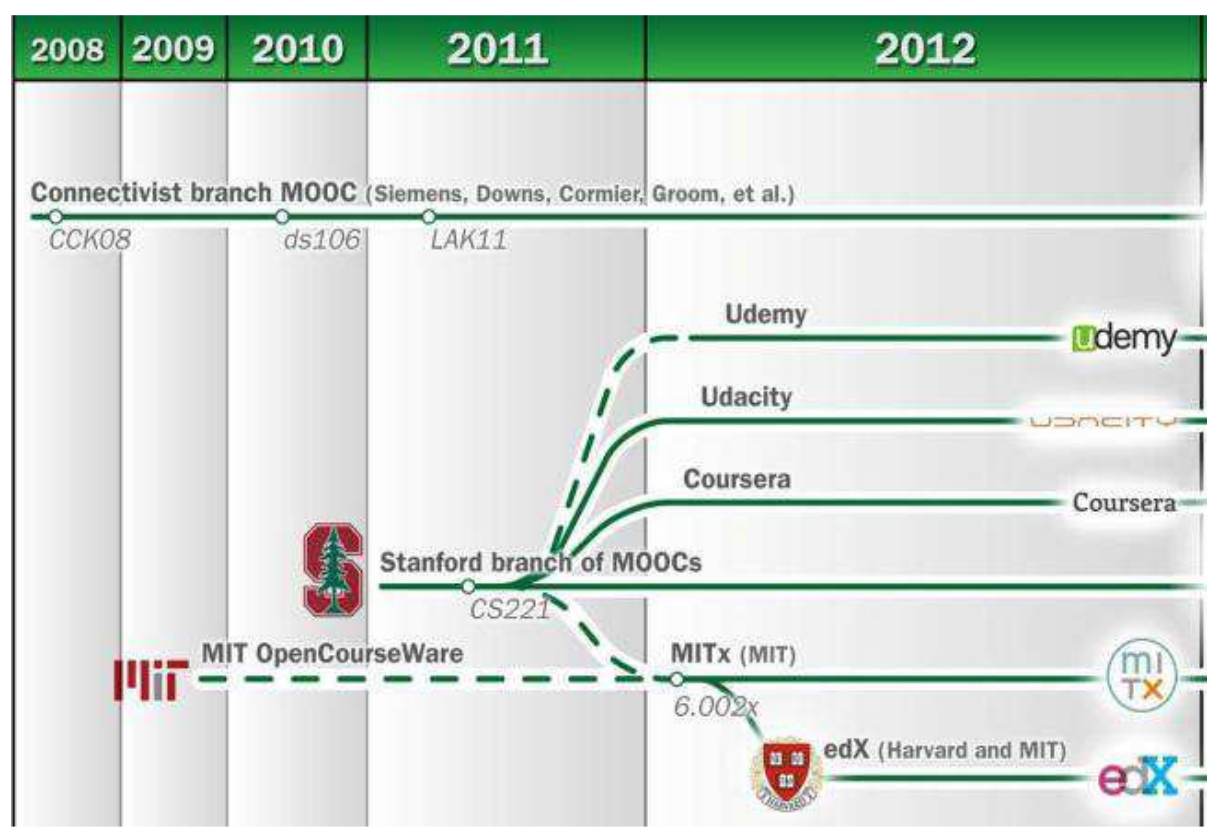

Figure 1. Timeline of MOOC development

In a blog post in July 2012, Downes (2012) proposed a new terminology: xMOOCs like Udacity, EdX, Coursera providing open online content, practice and activities in the domain in question [22].

xMOOCs appear to have developed out of the idea of Open Course Ware and Open Educational Resources. The " $x$ " in $x M O O C$ doesn't stand for anything specifically. But xMOOCs are typically offered by a university in partnership with a for profit organization. While edX and MITx have an " $\mathrm{x}$ " in their title, they are not the only organizations offering xMOOCs. M.G. Jones thinks of the " $x$ " standing for "Expert" because most of these MOOCs are offered by relying on recorded experts' lectures at well-known universities [21].

The XMOOC platforms have got a huge popularity and a lot of students were enrolled to the courses provided by these platforms. The next diagram represents the course distribution by providers as of year 2015 [32]. 


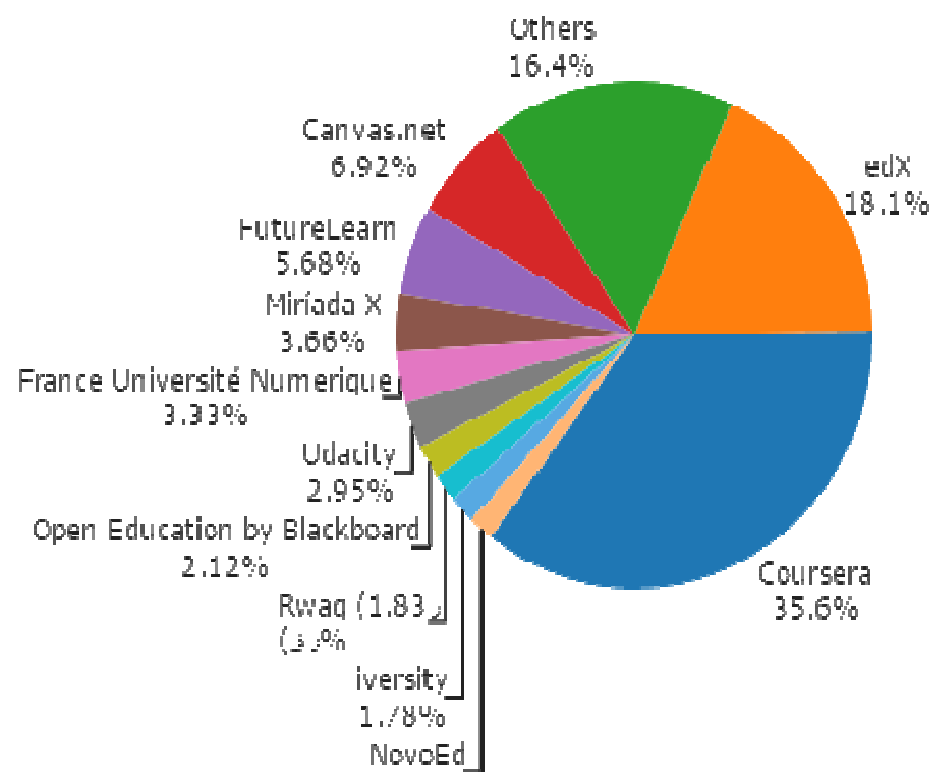

Figure 2. Course distribution by providers

L. F. Panchenko lists the following characteristics of cMOOC and xMOOC [30]:

Differences between cMOOC and xMOOC

\begin{tabular}{|c|c|}
\hline cMOOC & xMOOC \\
\hline Knowledge is being created and generated & Knowledge is being duplicated \\
\hline Creativity & $\begin{array}{c}\text { A more traditional approach } \\
\text { (video lectures, questionnaires, tests) }\end{array}$ \\
\hline $\begin{array}{c}\text { Are not financed } \\
\text { pedagogical society }\end{array}$ & Are financed \\
\hline $\begin{array}{c}\text { A large volume of unstructured information } \\
\text { Uncontrolled }\end{array}$ & Are supported by prestigious universities \\
\hline Volunteer team & Controlled \\
\hline
\end{tabular}

Basing on the table we can make a conclusion that XMOOC has corrected cMOOC's disadvantages to some extent and the process of xMOOC forming has considered the globalization of an economy, education and finance so they are more expedient to be used in modern universities.

MOOCs are built on the active engagement of several hundred to several thousand "students" who self-organize their participation according to learning goals, prior knowledge and skills, and common interests.

Unlike traditional distance learning courses (DC) all MOOC projects have the following features: engaging the best academic staff; availability of schedule and deadlines; the availability of numerous channels of feedback: listener-teacher, listenerlistener; free of charge; mass and globality. Until recently, online courses were "tracings" of the traditional university courses. MOOC differs in terms of the number of the participants, nonlinear type of relationships, and the principle of interaction between participants of the educational process. Nozdrina L.V. argues that the differences between designing projects of MOOCs and traditional distance courses can be viewed according to the main aspects presented in next table. 
Differences between developing the Traditional DC and MOOC projects

\begin{tabular}{|c|c|c|c|}
\hline \multicolumn{2}{|c|}{ Aspect } & Traditional DC & MOOC \\
\hline \multicolumn{2}{|c|}{ Platform } & $\begin{array}{l}\text { Moodle, eLearning Server, } \\
\text { Learning Space } 5.0\end{array}$ & $\begin{array}{c}\text { edX, Coursera, Udacity, Unimooc, Khan } \\
\text { Academy, } \\
\text { Open Learning Initiative, MIT } \\
\text { Opencourseware, Canvas }\end{array}$ \\
\hline \multirow{5}{*}{ Content } & $\begin{array}{l}\text { multimedia } \\
\text { creating }\end{array}$ & $\begin{array}{c}\text { Lack of own tools of } \\
\text { multimedia content } \\
\text { development }\end{array}$ & $\begin{array}{l}\text { The ability to create their own multimedia } \\
\text { content }\end{array}$ \\
\hline & $\begin{array}{l}\text { structure } \\
\text { features }\end{array}$ & $\begin{array}{l}\text { Required elements: the } \\
\text { preface, the authors of the } \\
\text { course, tutor, course news, } \\
\text { course program, frontpage } \\
\text { of the lesson }\end{array}$ & $\begin{array}{l}\text { Consist of short video lectures (10-15 } \\
\text { minutes), control tasks and the final exam. The } \\
\text { important point is the principle of selectivity. }\end{array}$ \\
\hline & language & Usually single-language & $\begin{array}{l}\text { Possibility to provide the course in any } \\
\text { language of the target audience }\end{array}$ \\
\hline & $\begin{array}{l}\text { length of } \\
\text { study }\end{array}$ & $\begin{array}{l}\text { From several months to a } \\
\text { year }\end{array}$ & From several weeks to several months \\
\hline & informative & $\begin{array}{l}\text { Only structured and } \\
\text { rendered basic information }\end{array}$ & Excess of non-structured data \\
\hline \multicolumn{2}{|c|}{$\begin{array}{l}\text { Education process } \\
\text { organization }\end{array}$} & $\begin{array}{l}\text { - organized under the } \\
\text { curriculum; } \\
\text { - regardless of the } \\
\text { number of participants. } \\
\text { The division of roles for } \\
\text { members (Administrator, } \\
\text { course author, tutor, } \\
\text { student, visitor) } \\
\text { - control the number of } \\
\text { covered material and the } \\
\text { quality of its assimilation }\end{array}$ & $\begin{array}{l}\text { - each participant of the course is building } \\
\text { his/her own way of study. } \\
- \text { the role of the learning process. such } \\
\text { services as diigo and twine redirect teachers } \\
\text { and students to the most popular information } \\
\text { resources. } \\
- \text { requires active participants as much as } \\
\text { possible for optimum performance. } \\
- \text { the role of the teacher and students in these } \\
\text { courses is insignificant. } \\
- \text { listeners must have a high level of } \\
\text { motivation and self-control. }\end{array}$ \\
\hline
\end{tabular}

The lifecycle of MOOC project as IT-project consists of the following phases: requirements analysis, design, development, implementation and evaluation.

It is obvious that like any approach in any sphere of activity the MOOC have some drawbacks, and limitations. They are listed below:

- insufficiency of practical tasks and student self-work assessment since only those tasks are used that can be formalized and verified automatically;

- limited opportunities of feedback, as even the best technology can't be compared with a "live" interaction;

- problems of plagiarism and identification arise due to the inability to test the independence of student's work or existence of his/her multiple accounts;

- issue of recognizing the certificate on successful completion of online courses by universities and employers;

- language barrier, as learning requires a sufficient level of knowledge of English etc.;

- motivation support for the successful completion of the online course;

- difficulty in the humanities assessment, however, recently this restriction is being attempted to be overcome by the collective assessment of achievements by the same students (peer assignment).

The students' enrollment for MOOCs is measured in thousands. Many of those people are working adults looking to pick up new technical or business skills, or update old ones, in order to advance their careers. But the real problem, generally, is that more than $70 \%$ of these 
would-be learners do not finish. Many of them do not even start the courses for which they are registered. And a lot of those who finish do not take another one. The next diagram shows the state of students' enrollment and graduation as of June 2015. The number of students who have finished courses stands between $0.9 \%$ and $41.6 \%$ [31].

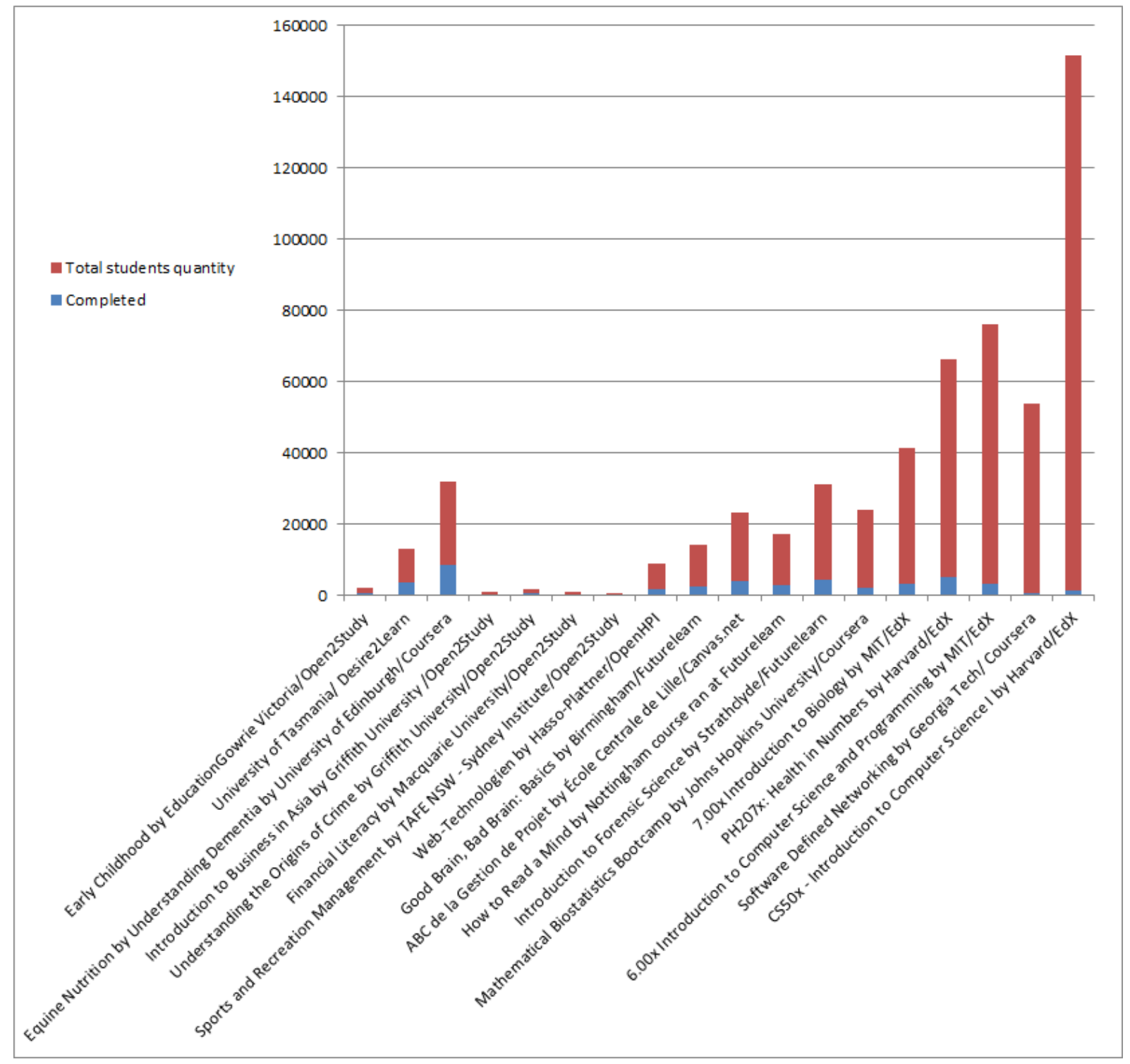

Figure 4. MOOC students' enrollment and graduation.

So why are all these students falling asleep, virtually, in their digital classes? It is the question that author Todd Tauber was asking in 2013. And he tried to give an answer. Mainly because the people putting education online are still thinking in terms of classrooms. Twentieth century instructional methods just do not work as well for busy, distracted 21 stcentury learners.

Another big issue, especially for non-traditional students, is that learning has to fit in between life and work. In a recent survey of MOOC students at Duke University, for example, the most commonly cited barrier to completion was "lack of time/amount of time required." That means that lessons should last as short time as possible. As of 2016 year the study period is approximately 3-12 weeks and it depends on what subject is being taught. 
Around $83 \%$ of college students, companies' workers and entrepreneurs spent much time on mobile apps. And this rate has been doubled in the last two years. Facebook, for one, recognized that most of its users are now coming from smartphones and tablets and that those people are engaging twice as much (in page views, interactions, consumption and production) as desktop or laptop users. That is the reason why educational online tools have to build their entire strategy around mobile.

"Mobile," however, means more than just delivering the same old content on smartphones or tablets. Mobile education needs to be tailored for smaller, more limited, more intimate mobile devices. That means the user experience needs to be more streamlined and intuitive than today's learning management systems. It also needs to be designed for the specific behaviors of mobile users. And mobile users are first and foremost easily distracted. More than $25 \%$ of them acknowledge that smartphones make it significantly harder to focus on a single task.

Mobile content, then, needs to be "bite-sized," visually stimulating and interactive because online there are maybe 5 to 10 seconds to grab people's attention (according to recent research by University of Massachusetts professor Ramesh Sitaraman). But in the age of information overload, good design and more content - even if it is short, beautiful, entertaining and accessible on any device - is not the whole answer because everyone has their personal interests and needs that are different. As Khan Academy president Shantanu Sinah recently noted: "Students right now are kind of forced into a system where they're pushed forward in almost an assembly line model." But, he adds, "you can use technology to personalize the instruction and target what their individual needs are. You can fill those gaps, and when you do that and when you empower students to do that ... the learning is so much more productive."

Online education also needs to do a better job leveraging peer interaction and collaboration. Most MOOCs do already promote discussions among classmates to help with homework and grading. But the emergence of Twitter and LinkedIn (and soon Facebook) as go-to sources of professional insights shows that people want to actually learn from, and work with, their colleagues and business contacts just as much as from $\mathrm{PhDs}$, editors and other experts. A recent Michigan State University study even found that students who used Twitter to engage with classmates as well as instructors "were more interested in the course material and ultimately received higher grades." [33]

The institution which has so far come the closest is the University of Phoenix. The university's new educational course, Innovator's Accelerator, developed with Silicon Valley design firm, IDEO, combines short videos and frequent assessments with facilitated group projects, asynchronous collaboration and innovative tools designed specifically to drive participation [33].

To our mind, shown results are not conditioned by MOOCs specificity. The problem lies in motivation for learning and ICT competencies of participants of mentioned courses. For example, less than $20 \%$ of students recognize the traditional teaching of programming in the form of trainings as effective for themselves. And this is despite the fact that the trainings are carried out by practicing programmers with extensive experience of programming teaching [26]. In this case we can talk about matching the results with the famous Pareto principle. This principle can be successfully applied for e-Learning projects [27-28]. Since MOOCs preferably have an open and voluntary character, the fact that their learning outcomes meet the Pareto principle should be taken for granted.

Longitudinal studies for understanding the nature, extent, and evolution of ad hoc communities, perhaps MOOC centered but not restricted to a single MOOC, would undoubtedly require data mining across larger spheres of Web interactions than is currently easy to do. Nonetheless, the possibilities for understanding of student patterns in seeking 
remedial and advanced material, instructor incentives for creating and posting material, and the movement of people between student and teacher roles, are exciting and within current technical abilities - if only the data could be accessed [29].

\section{THE CONCLUSIONS AND PROSPECTS OF FURTHER RESEARCH}

In recent decades e-Learning system has experienced a lot of revolutionary changes that are directly related to the rapid growth in the development of information technology. Many technical resources and means, and, consequently, many ideas of their application in the educational process have arisen and continue to arise.

Under the conditions of ongoing globalization of society, economics, law and education the 20th century methods of instruction should be used in close connection with the latest technological advancements. The use of educational methods in a form in which they existed 50 years ago leads to a significant gap between them and the actual state of affairs in the IT sphere where present/current and future university students spend their time. Hence, scientists are striving to build more efficient models to drive innovation and utilize communication resources to improve the training process.

The process of improving the efficiency of educational tools and methods based on technological advancements has a considerable history. As we can see, e-Learning system has expanded its toolkit in accordance with technological progress. Without any doubts, the most significant breakthrough of the 20th century which opened up unparalleled opportunities for e-Learning system is the advent of the Internet.

And here we can say about regular appearance of MOOCs, which are a logical continuation of the development of e-Learning. In addition, today MOOCs are a means of implementation of the principles of openness in education, which is one of the important tasks of the last century. Openness of education, its availability for everyone and at any time, particularly - these are things that are realized by means of MOOCs.

We cannot but admit that just like any approach in any human activity, the above mentioned educational tools have their limitations and drawbacks, such as the language barriers or the number of students enrolled in the courses. The latter can be explained by low motivation, but traditional approach is confronted with the same problem. It can be overcome by increasing the importance of the certificate obtained after course completion.

A number of limitations and disadvantages can and should be reduced in order to build an efficient system of education that will be able to respond to the needs of consumers of educational services.

Many observers and educators believe that the advent of MOOC has become a revolution in higher education, but it should be borne in mind that it is not a kind of panacea, but merely a means to increase the value of educational services. Due to its novel character, there are many things to be explored, tested and applied in order to ascertain the use of such an educational platform in higher education.

The article gives a start for further research into the e-Learning platforms and tools. Besides, the research has important implications for comparative analysis of national and foreign experiences of MOOC projects' implementation and ways of their application for teaching IT and particularly programming courses to students.

\section{REFERENCES}

1. Behera S. K. E- and m-Learning: a comparative study. / S. K. Behera// International Journal on New Trends in Education and Their Implications. - 2013. - №4. - Available from: http://www.ijonte.org/FileUpload/ks63207/File/08.behera.pdf 
2. Aparicio M. An e-Learning Theoretical Framework. / M. Aparicio, F. Bacao, T Oliveira // Educational Technology \& $\quad$ Society. $\quad$ - $\quad 2016 . \quad$-№1(19). $\quad$ - Available from: http://www.ifets.info/journals/19_1/24.pdfhttp://www.ifets.info/journals/19_1/24.pdf

3. Glazunova O. Theoretical and methodological bases for the design and application of an e-learning system for future IT specialists in an agrarian university. Thesis dis. dr. ped. sciences: 13.00.10/ O. Glazunova NAPS Ukraine. // Institute of Information Technologies and Learning Tools of NAES of Ukraine. Kyiv, 2015. - 41 p. (in Ukrainian)

4. Skinner B.F.: The science of learning and art of teaching. // Harward Education Review, Spring, 24, 1954.- P. 86-97

5. Merge B.: Instructional Design \& Learning Theory. / B. Merge // Learning Theories of Instructional Design. $\quad-1998 . \quad$ May -Available from: http://citeseerx.ist.psu.edu/viewdoc/download?doi=10.1.1.645.7122\&rep=rep1\&type=pdf

6. Anderson T. The theory and practice of online learning. Second Edition. / T. Anderson. -Edmonton: AU Press. - Available from: http://web.mef.hr/web/images/pdf/a_online_learning.pdf

7. Attel U. Training computer: simulation in the true scale of time of learning dialogue /U. Attel// Cybernetics and learning problems. / Ed. and foreword Berg A.I. -Moskov: Progress, 1970. - 465 p.

8. Michalski R.S. Machine Learning: An Artificial Intelligence Approach / R.S. Michalski, J.G. Carbonell, T.M. Mitchell. - Berlin: Springer-Verlag, 1983. - 525 p.

9. Ramskyi Y.S. Balyk N.R. Methodological foundations of learning the expert systems at school. / Y.S. Ramskyi, N.R. Balyk - Kyiv.: 1997. -134 p.

10. Morri A.: A bright future for distance learning. / A. Mori // Telephony. - 1997.- Vol. 233, Issue 20. - p. 72.

11. Rosenberg M. E-Learning: Strategies for delivering knowledge in the digital age. /. - Columbus, OH: Mcgraw-Hill. - 2001. - 346 p.

12. Cernat M.: Ethical challenges of the e-learning system. / M. Cernat // Challenges of the Knowledge Society. Education and Sociology.-Available from: http://cks.univnt.ro/uploads/cks_2013_articles/index.php?dir=3_Administrative_and_Political_Sciences\% 2F\&download=cks_2013_administration_019.pdf

13. Sharples M.: Big Issues in Mobile Learning. / M. Sharples // Report of a workshop by the Kaleidoscope Network of Excellence Mobile Learning Initiative. - University of Nottingham, 2006. - 34 p. .Available from: http://matchsz.inf.elte.hu/tt/docs/Sharples-20062.pdf

14. Georgiev S.T. M-learning - a new stage of e-learning. // Conference: Proceedings of the 5th international conference on computer systems and technologies. - June 2004. - Available from: https://www.researchgate.net/publication/262367952_M-learning-a_new_stage_of_e-learning

15. García M.G. Development and evaluation of the team work skill in university contexts. Are virtual environments effective? / M.G. García, C.B. López, Molina E.C., Casas E.E., Ruiz-Morales Y.A. // International Journal of Educational Technology in Higher Education. - (2016), 13:5. - Available from: http://educationaltechnologyjournal.springeropen.com/articles/10.1186/s41239-016-0014-1

16. Danielh J. S: Mega-universities and Knowledge Media: Technology Strategies for Higher Education. London: Psychology Press, 1998. - 212 p.

17. Morze N.V What Should be E-Learning Course for Smart Education / N.V. Morze., O.G. Glazunova // Workshop ICTERI 2013. - Available from: http://ceur-ws.org/Vol-1000/ICTERI-2013-p-411-423MRDL.pdf

18. Singh H. Building Effective Blended Learning Programs./ H. Singh// Educational Technology. - 2003. Vol.43, $\quad$ Number 6.60 Available http://www.asianvu.com/bk/UAQ/UAQ_WORKSHOP_PACKAGE/new/Appendix\%20B\%20$\%$ 20blended-learning.pdf

19. McAuley A. The MOOC model for digital practice. / A. McAuley, B. Stewart, G. Siemens, D. Cormier.Available from: http://www.elearnspace.org/Articles/MOOC_Final.pdf

20. Hollands M.F., Tirthali D.: MOOCs: Expectations and Reality. Full Report / M. Hollands, D. Tirthali. Available from: content/uploads/2014/05/MOOCs_Expectations_and_Reality.pdf

21. Jones M.G. Types of MOOCS: c-MOOCS \& x-MOOCS / M.G. Jones - Available from: http://oertools.weebly.com/types-of-moocs.html

22. Levy D. Two Types of MOOCs: An Overview / Levy D// Adult Education in Israel. - 2014, №13. Available from: http://cms.education.gov.il/NR/rdonlyres/ECC22EA4-F932-420C-AA4ECEDF2CB9002D/185084/8DalitLevyTwoTypesofMOOCs.pdfhttp://cms.education.gov.il/NR/rdonlyres/ ECC22EA4-F932-420C-AA4E-CEDF2CB9002D/185084/8DalitLevyTwoTypesofMOOCs.pdf

23. Kuzmenko H.M, Horolskyi O.V.: Massive open online course in the context of integration of the higher education of Ukraine. / H.M. Kuzmenko, O.V. Horolskyi // Pedagogical sciences. Collection of papers / 
Poltava V.G. Korolenko National Pedagogical University. - Available from: http://dspace.pnpu.edu.ua/bitstream/123456789/4858/1/Kuzmenko.pdf (In Ukrainian)

24. Bykov V., Shyshkina M. Innovative models of education and training of skilled personnel for high tech industries in Ukraine / V. Bykov, M. Shyshkina //Journal of Information Technologies in Education. 2013. - №15. - Available from: http://ite.kspu.edu/webfm_send/388

25. Selingo J. J.: Demystifying the MOOC / J. J. Selingo // The New York Times. - 2014, Oct. 29. Available from: http://www.nytimes.com/2014/11/02/education/edlife/demystifying-the-mooc.html?_r=0

26. Morse N.V. Wykorzystania projektów start-up do tworzenia kompetencji Business Informatyki. / N.V. Morse, N.R. Balyk //Cieszyński Almanach Pedagogiczny, Czasopismonaukowe, UniwersytetŚląski. Katowice-Cieszyn - 2015. - №3. - P. 179 - 188. (in Polish)

27. Pocatilu P. Measuring the Efficiency of Cloud Computing for E-learning Systems / P. Pocatilu, F. Alecu, M. Vetric // Wseas transactions on computers. - 2010, Issue 1, Volume 9.- Available from http://www.wseas.us/e-library/transactions/computers/2010/89-159.pdf

28. Stuart Jr D. Here's Why the 80/20 Rule Matters for Educators. -Available from http://www.davestuartjr.com/80-20-rule/

29. Bruff D. O, Fisher D. H., McEwen K. E., Smith B. E.: Wrapping a MOOC: Student Perceptions of an Experiment in Blended Learning. / D. O. Bruff, D. H. Fisher, K. E. McEwen , B. E. Smith // MERLOT Journal of Online Learning and Teaching. - 2013, Vol. 9, № 2 .- Available from http://jolt.merlot.org/vol9no2/bruff_0613.pdf

30. Panchenko L.F.: Massive open online course as alternative form of increasing of teacher qualification of higher school. / L.F. Panchenko // Education and science teacher. - 2013, №1 (156). - Available from http://www.irbis-nbuv.gov.ua/cgibin/irbis_nbuv/cgiirbis_64.exe?C21COM=2\&I21DBN=UJRN\&P21DBN=UJRN\&IMAGE_FILE_DOW NLOAD=1\&Image_file_name=PDF/OsDon_2013_1_4.pdf

31. MOOC Completion Rates: The Data. - Available from http://www.katyjordan.com/MOOCproject.html

32. D. Shah By The Numbers: MOOCS in 2015. - Available from https://www.classcentral.com/report/moocs-2015-stats/

33. Todd Tauber: The dirty little secret of online learning: Students are bored and dropping out. -Available from http://qz.com/65408/the-dirty-little-secret-of-online-learning-students-are-bored-and-dropping-out/

34. Spirin O. M. Criteria and quality indicators of information and communication technologies of learning: O. M. Spirin // Information Technologies and Learning Tools. — 2014. — №1 (33). — Available from: http://journal.iitta.gov.ua/index.php/itlt/article/view/788\#.Uzz9i_1_t1Z. (in Ukrainian)

Text of the article was accepted by Editorial Team 20.09.2016

\title{
МАСОВІ ВІДКРИТІ ОНЛАЙН-КУРСИ ЯК ЕТАП РОЗВИТКУ ЕЛЕКТРОННОГО НАВЧАННЯ
}

\author{
Березицький Микола Михайлович \\ аспірант \\ Інститут інформаційних технологій та засобів навчання НАПН України, Київ, Україна \\ m.berezitskyi@gmail.com
}

\section{Олексюк Василь Петрович}

кандидат педагогічних наук, викладач кафедри інформатики та методики ії навчання Тернопільський національний педагогічний університет імені Володимира Гнатюка, Тернопіль, Україна oleksyuk@fizmat.tnpu.edu.ua

Анотація. У статті проаналізовано історичний процес розвитку e-Learning, який включає в себе появу мобільного навчання (m-Learning), Smart-університетів, масових відкритих онлайн-курсів (МВОК), хмарних технологій. Особлива увага приділяється дослідженню феномену МВОК, зокрема, двох їх типів - кМВОК та хМВОК. Авторами здійснюється порівняння обмежень i недоліків МВОК та традиційного навчання, аналізуються статистичні дані щодо використання МВОК-платформ, а також кількості студентів, що реєструються та успішно завершують масові відкриті онлайн-курси. Стаття містить аналіз відмінностей між традиційними дистанційними курсами та МВОК, а також розкриває основні проблеми останніх. 
Ключові слова: електронне навчання; мобільне навчання; масові відкриті онлайн-курси відкрита освіта; кМВОК; хМВОК.

\title{
МАССОВЫЕ ОТКРЫТЫЕ ОНЛАЙН-КУРСЫ КАК ЭТАП РАЗВИТИЯ ЭЛЕКТРОННОГО ОБУЧЕНИЯ
}

\author{
Березицкий Николай Михайлович \\ аспирант \\ Институт информационных технологий и средств обучения НАПН Украины, Киев, Украина \\ m.berezitskyi@gmail.com
}

\section{Олексюк Василий Петрович}

кандидат педагогических наук, преподаватель кафедры информатики и методики ее обучения Тернополь, Национальный педагогический университет имени В. Гнатюка, Тернополь, Украина oleksyuk@fizmat.tnpu.edu.ua

\begin{abstract}
Аннотация. В статье проанализирован исторический процесс развития e-Learning, который включает в себя появление мобильного обучения (m-Learning), Smart-университетов, массовых открытых онлайн-курсов (МООК), облачных технологий. Особое внимание уделяется исследованию феномена МООК, в частности, двух их типов - кМООК и хМООК. Авторами осуществляется сравнение ограничений и недостатков МООК и традиционного обучения, анализируются статистические данные использования МООК-платформ, а также количества студентов, которые регистрируются и успешно завершают массовые открытые онлайн-курсы. Статья содержит анализ различий между традиционными дистанционными курсами и МООК, а также раскрывает основные проблемы последних.
\end{abstract}

Ключевые слова: электронное обучение; мобильное обучение; массовые открытые онлайн-курсы открытое образование; кМООК; хМООК.

Conflict of interest. The authors have declared no conflict of interest.

\section{(cc) BY-NC-SA}

This work is licensed under Creative Commons Attribution-NonCommercial-ShareAlike 4.0 International License. 